\title{
Digital Games and Interactive Activities: Design of Experiences to Enhance Children Teaching- Learning Process
}

\author{
Natália Brunnet \\ PUC-Rio/Department of Arts and Design, Rio de Janeiro, 22451-900, Brazil \\ Email: nataliabrunnet@gmail.com \\ Cristina Portugal \\ PUC-Rio/Department of Arts and Design, Rio de Janeiro, 22451-900, Brazil \\ Email: crisportugal@gmail.com
}

\begin{abstract}
This paper discusses teaching-learning experiences for children using today games and digital interactive activities in order to understand the benefits and difficulties for their use. This study also contextualizes the subject under the light of authors from the fields of design and education, resulting in conclusions about the relationship between the advancement of technology, its integration into the school and the effectiveness of new digital materials designed today.
\end{abstract}

Index Terms-Children teaching-learning, interactive activities, digital games, interdisciplinary, design, technology.

\section{INTRODUCTION}

We are living in a moment of constant technological innovations, increasingly faster, and of different visions about the dynamics of the teaching-learning, current and future. Ramal (2003) highlights that with the speed in which information flows and is produced today, it is no longer possible to assimilate a large part of the knowledge needed to have a job and to imagine that this will be enough for the remaining of the life. Just understanding and memorizing the knowledge that humanity produced until today would not be enough for training people. For Silva (2003), today, the great evolution is to receive the experience, which is different from receiving the information.

Reflections such as that are being globally discussed. For the Education Secretary of the United States of America, Arne Duncan (2015), we live today in a global economy with a market based on knowledge. According to him, the measure of our success is becoming less about what we know, and more about what we do with what we know and about learning new skills in order to adapt to a quickly changing world. Prensky (2001) says that, in order to educate today, we must reconsider both the methodology as well as the new content that have to be taught. The author highlights that those new technologies, which are originally digital, must be invented in all levels, using the students as our guides.

In this moment of strong transition between the model of books, encyclopedias and explanatory classes to a new model not yet exactly known by nobody, it is notorious that new types and formats of digital materials should be used in classroom education. Those can be interactive exercises, games and digital activities, animations, electronic books, simulations, applications, videos and podcasts. Teachers and students in the school environment are already using those objects today.

Besides transformations coming from the excess of information and what we should do with it, it is important to highlight that those materials are created in face of a need, because "today's students are no longer the people our educational system was designed to teach" (PRENSKY, 2001 p.1). According to the author, current students are digital natives who think and process information in a fundamentally different way than their predecessors, the digital immigrants, category in which their current teachers are framed. The trend is that digital natives will learn with new tools and languages and will resist to the old ways of communicating and learning.

In face of what was exposed, this paper has the objective of understanding, illustrating and discussing the benefits and difficulties on the use of some of those educational objects. Mainly, games and digital interactive activities, in the process of teaching-learning, mapping their types and uses and the systems in which they are inserted, as well as aspects that must be considered during their projects. First, this paper will present, in general lines, a literature review concerning games and digital activities. It will also present the analysis of four digital learning experiences with photos and schemes and the closing remarks of the study.

\section{About Design In ChILDREN TEACHING-LEARNING SITUATIONS}

The design in teaching-learning situations enhances the process of construction of knowledge and "each design 
solution represents the search for balance between the interests and needs of the teacher and the student, as well as the ones of educational institutions" (PORTUGAL, 2013 p.17). Regarding some of the possible solutions, the use of games, drawings and dramatizations, according to Piaget (1975), may contribute for the cognitive development of the child between 2 and 7 years old. In this period, the child creates mental images even without using objects; it is a phase of fantasy and "make-believe".

Regarding the content to be taught, Shulman (1986) understands that once knowledge is identified as a teaching object, a series of adaptations is needed to transform it into something that can be taught and learned. Even because, according to Freire (1996), teaching is not a synonymous of transferring knowledge, but of creating possibilities for its production or building. Under the same light, Prensky (2001) believes that digital games are an example of the successful adaptation of teaching materials to the current language.

Teaching materials created today must instigate the exploration of the knowledge, the critical behavior and be focused on the "learning to think" and on the "learning to learn". Arne Duncan (2015) explains precisely the vision that must be used to design them by stating that innovation in education must not focus only on the most recent gadget or application, but in how the technological tools may capacitate students to become who they want to be and what the world needs then to be.

Thus, by developing games and activities, the designers, teachers and developers must wide their vision beyond the objects themselves. They need to think about the whole system in which those artifacts will be used, considering the behavior of the target and of all parts involved, the objective, the process and the results, because this is how the good experiences of teachinglearning will be born.

\section{BENEFITS AND DifFICUlTIES OF DigitAl ACTIVITIES AND GAMES}

In the teaching-learning context, digital activities and games have similarities, but cannot be considered as the same product. This paper will consider both objects as being similar regarding their projects, types and educational uses.

Digital activities focused on education are materials that may aggregate different elements such as simple games, audios, exercises, simulations and animations. Those objects may work both independently as well as be related with others, being a complementary part of a set, which makes the teaching material of a given curriculum.

Regarding games, many authors (Huizinga, 1971; Bruner, 1992; Battaiola, 2000; Vianna, 2013) talk about the attributes that differentiate them from other activities, detailing the specific characteristics and possible classifications. In common with interactive activities, there is the existence of an objective (goal), interactivity and entertainment. Specific characteristics of games are, for instance, the presence of a player and adversary, defined rules and conditions of victory, draw and defeat.
Huizinga (1971) and Vianna et al (2013) claim that the game must be a free and non-structured activity. Mcgonigal (2012) adds to this list the presence of a feedback system and voluntary participation. Regarding the rules, Vygotsky (1991) makes a counterpoint stating that "the imaginary situation of any kind of toy already has behavior rules, although it may not be a game with formal rules established a priori" (VYGOSTKY, 1991 p.63). Vianna et al (2013) classifies games as analogical, digital and pervasive, as follows:

- Analogical: table games (Mikado, RPG), card games (UNO, Magic), dice games (Craps), games with paper and pen (Crosswords, Tic-tac-toe, Stop/Adedonha), field (Soccer) or court games (Basketball), group dynamics and entertainment games.

- Digital: videogames, games in application format and simulators.

- Pervasive: games using equipments such as Kinect, Xtian and Rift glasses.

According to this classification guideline, this paper will approach the digital and pervasive games. Under the perspective of applications modes, the games and interactive activities may be used by direct interaction of the student or by means of an educator; individually or in group; with or without the simultaneous use of other materials/objects. Regarding their objective or teaching function there are also different approaches such as presenting new content, content fixation, revision or evaluation.

Those educational objectives create an active interest on children, because they are an essential part of the interaction and experience performed. The generated emotion creates a situation of engagement and flow (CSIKSZENTMIHALYI, 1990), favoring the learning and memorization of the educational content. Those materials are also excellent tools for performing simulations because they explore and build situations beyond text and image, which become kinesthetic experiences. They are versatile to all disciplines and contexts, from the basic and essential ones such as learning colors, presented in two cases on this paper, until mathematics, biology or geography foundations, for instance, that have not easy to learn concepts.

In order to understand the fundamental functions of the game, ideas of Bruner (1992) are here used, suggesting approaching the theme of the relationship between game, language and thought, examining its practical implications such as organizing the activities of the children in game groups in order to help them to develop their potential and to live more fully. The fundamental functions of the game in children activity are then synthesized.

- $\quad$ Function 1 - first of all, in the game the severity of the consequences of errors and failures is reduced. In effect, the game is a serious activity that has no frustrating consequences for the 
children and is justified by itself. The game may be considered an excellent way of exploring that awakes stimulus by itself.

- $\quad$ Function 2 - secondly, the game is characterized by a quite fragile connection between the means and the goals. It does not mean that children are not looking for finality and not using the means to obtain them in the game, but what happens is that children change objectives while actuating, in order to adapt themselves to the new means or vice-versa, and also by emotion and happiness. The game serves as a way of exploring and also of invention. In the game children are not very worried with results, but they modify what they are doing in order to leave the way free for their fantasy. If they cannot interfere on it, they tend to become quickly bored with the activity. When observing a child stacking wood blocks, it could be surprising the diversity and richness of combinations that it introduces on the game, offering a unique opportunity to enrich the banality.

- Function 3 - on the third place, besides its variety, the game is seldom random or casual, on the opposite, it normally has rules. Sometimes those rules are harder to discern, however, it is always worth to look closely, which is the formal finality of a game.

- Function 4 - on the fourth place, it is normal to say that the game is a projection of the inner life towards the outer world, contrasting with learning, by means of which the external world is internalized and becomes part of the individual. The game is an extremely important activity for growing. Playing creates a very particular feeling of omnipotence that may be entrancing and sometimes even scaring.

To all that it must be added the fact that the game entertains and entertains a lot. Even objects placed on the game to be overcome become fun. In fact, those obstacles seem to be necessary, because with the lack of challenges, the child tends to become quickly bored. For McGonigal (2012), reality does not motivate people effectively, because it is not inherently designed to make them happy. In this sense, Bruner (1992) believes that it is possible for people to assimilate the game in order to solve real problems in a more pleasant way. Thus, if the game is not considered as a source of entertainment, people will not really understand what it is all about. (BRUNER apud PORTUGAL, 2010, p: 163-164).

Although it is clear that games may help the teachinglearning process, Tractenberg e Tractenberg (2012), alert that, among the several things that may go wrong in educational projects, one with a large impact is the use of inadequate educational materials and technological resources. Costa (2009) points to a lack of planning for integrating games in the teaching-learning environment, by highlighting a difficulty in the application of games: "what exists, most of the time, are well intentioned teachers trying to make their classes more entertaining in order to keep the attention of the students about what is being taught or exercised" (COSTA, 2009, p.12). This is one of the difficulties of using educational digital games also pointed by Grando (2000). The author organized disadvantages raised by scholars such as Kishimoto, Machado, Corbalán and Giménez, as follows:

- When games are misused, there is the danger of giving a merely random character to the game that becomes an "appendix" in classroom. The students play and feel motivated only by the game, not knowing why they are playing it.

- Time spent with game activities in classroom is larger and, if the teacher is not ready, there may be a sacrifice of other contents due to the lack of time.

- Misconceptions that all contents must be taught by means of games. Thus, classes normally become casinos, also making no sense for the students.

- The lack of "playfulness" of the game due to the constant interference of the teacher, destroying the essence of the game.

- The coercion of the teacher, demanding that the student play, even if it does not want to, destroying the voluntariness that is part of the nature of the game.

- The access and availability difficulty of materials and resources about the use of games in teaching, which may subsidize the teaching work.

For Grando (2000), those considerations propose that the teacher "takes a proposal of working with games as an option, based on a reflection with methodological assumptions, previewed on its teaching plan, linked with a coherent conception present on the school planning as a whole" (GRANDO, 2000 p.35).

Those statements show that the effort for involving teachers in those new teaching experiences must be greater, so that in the same way as the students, they also integrate into a dynamics that already changed and is still changing. It is worth to remind that teaching materials are not only tools for the student learning as well as for the educator's work.

\section{TEACHING-LEARNING EXPERIENCES WITH DIGITAL GAMES AND INTERACTIVE ACTIVITIES}

Aiming to deepen the reflection about the ideas previously exposed, hereafter four cases are detailed reporting the application of games and digital activities in the context of childhood education, as well as the analysis of this interaction, in order to illustrate how those materials are being used, the systems in which they are inserted in and the important methods and techniques to project them.

\section{A. In Digestion and Treasure Puzzle: learning objects in schools of New Zealand and Australia}


In 2001 the governments of Australia and New Zealand funded with over 68 million dollars the development of learning objects for primary and high schools. Those objects were games and educational activities to be used in computers. After the development and use of those materials in schools, a field research performed in 2004 by Murdoch University analyzed their use in classroom.

In a paper highlighting two games from this study "In Digestion" and "Treasure Puzzle", Lowe et al (2010) talk about the usability and efficacy of those materials by investigating if/how students engaged with the learning objects. The methodology used had different techniques such as participative observation, interviews and questionnaires in order to answer if the students were able to easily use the materials, if they liked the experience and if they engaged with the content aimed to be taught.

"In Digestion" game was one of the best evaluated among all developed objects and had the characteristics of being hard, surprising and fun. Besides, it related with the day-to-day by creating interactions from a theme that is of intrinsic interest and personal importance.

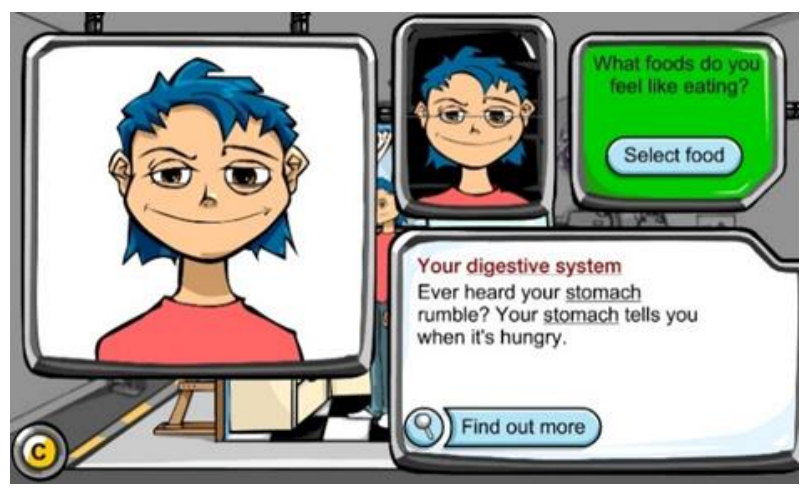

Fig.1. Interface of "In Digestion” game. Source: Lowe et al (2010).

The "Treasure Puzzle" created a deviation from the content intended to be taught, with a mechanics that created lack of interested by the students. The game did not provide feedback from the data inputted by the students, had concepts and words that were not familiar to the students and some of its activities had very long texts.

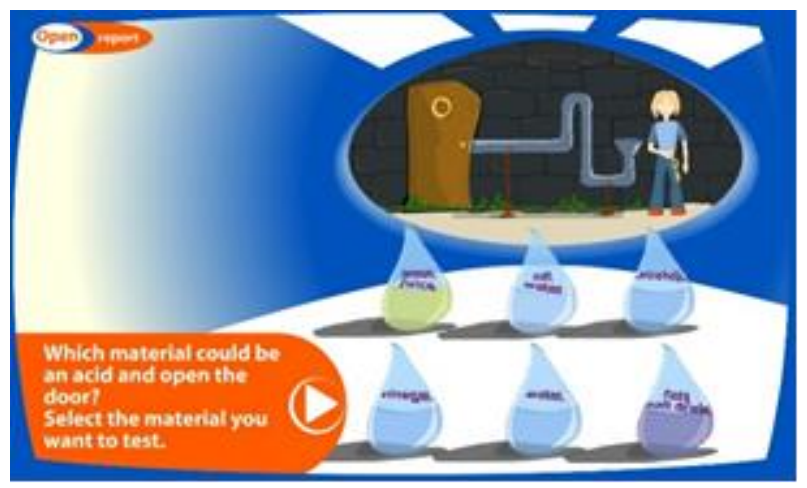

Fig.2. Interface of “Treasure Puzzle” game. Source: Lowe et al (2010).

\section{B. Beelight: digital manipulable to help children during the discovery of colors}

Shen et al (2013), researchers from Zhejiang University, started a study from the following paradigm: technology has being integrated into school, but the method for teaching colors for children continues to be the traditional one: adults show to children cards or colored objects and tell the name of colors. According to the researchers, this makes students learn and accept information instead of helping them to discover and explore the knowledge. This fact led to the "Beelight" project. In their paper "Beelight: helping children discover colors", the authors describe the project of developing Beelight, a manipulable object to help children between four and six years to discover colors.
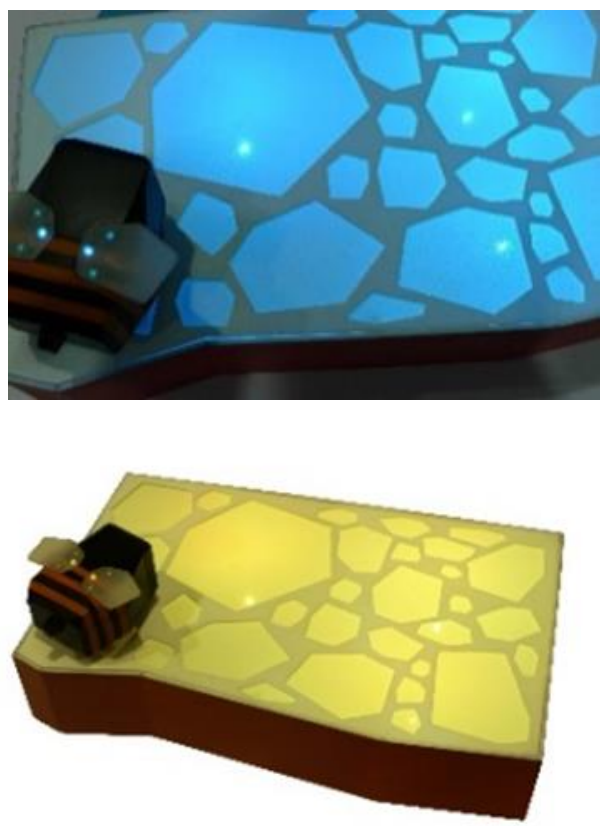

Fig.3. Digital manipulable "Beelight”. Source Shen et al (2013).

In order to build the toy, the researchers used the method of participative investigation. They organized three workshops with the participation of the children and two educators. Initially, an observation about the traditional teaching of colors was performed and, on the next week, researchers carried the first prototype for tests with the children. Tim Brown (2010) defines that the prototype is any tangible thing that allows us to explore an idea, evaluate it and they carry it forward. The dynamics performed with the first prototype helped to improve it from the feedback of children and teachers. 


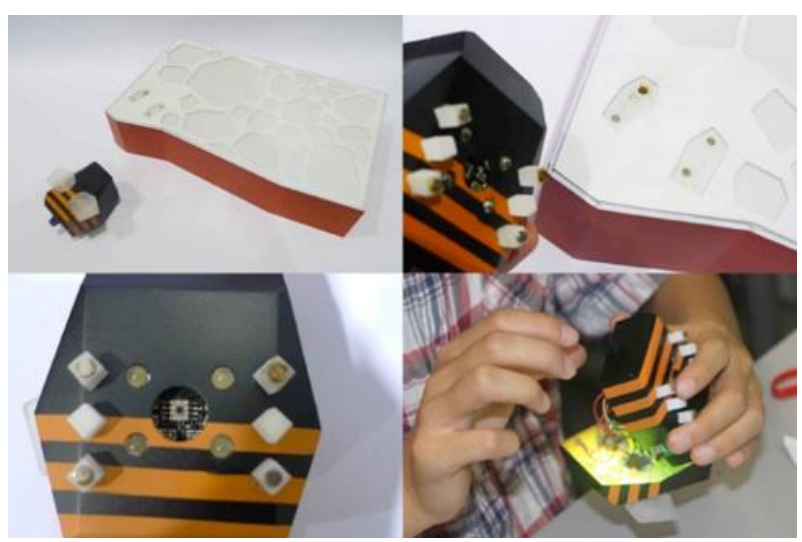

Fig.4. Details of "Beelight” components. Source: Shen et al (2013).

The manipulable worked as follows: a collector could be placed over any object in order to capture its color and then the collector was placed over a platform. When it was left over the platform, that one would assume the captured color.

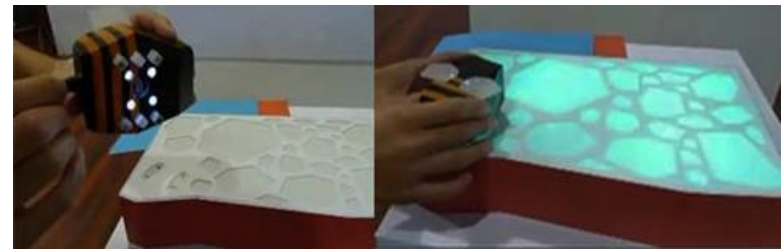

Fig.5. Manipulable and platform composing the "Beelight". Source: Shen et al (2013).

Interactive prototyping allowed the creation of a new functionality that was not imagined by the researchers. Beelight now has another mode, in which the platform randomly displays a color and the children should place the manipulable over an object of the same color. This last mode, in fact, was the one that created more engagement from students. According to researchers, some children quickly lost interest in using just the first mode of the toy.

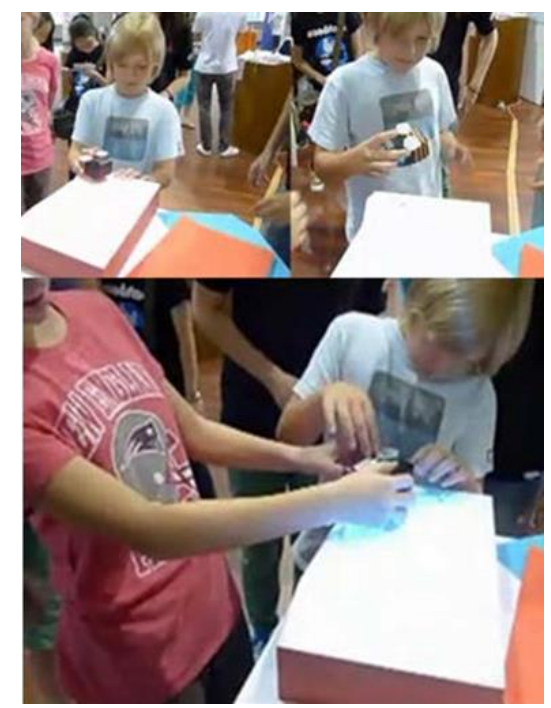

Fig.6. Children playing with "Beelight”. Source: Shen et al (2013).
It is important to highlight that with this case in which the observation of users and context, the methodological decision by participative investigation and the technique of iterative prototyping were essential to improve the object, reaching the educational goal and getting engagement from children.

\section{The Goalkeeper: interactive game for motor development and English teaching}

Developed by researchers from Taiwan, Hsiao and Chen (2016), the Goalkeeper game combined the technology of gesture-based computing and game-based learning.

According to researchers, the gesture-based technology of equipments such as Kinect and Xtion improves the gross motor coordination, memorization, motivation and learning capacity and performance on several disciplines. The game-based learning model, already well spread in schools today, engage students to learn by means of an interactive entertainment, promoting the flow state. Thus, a learning model aggregating characteristics from both and adequate for preschoolers was developed: the gesture-based games.

The study was performed with the help of the gamebased learning from Garris, Ahlers, and Driskell (2002), known as Input-Process-Outcome (IPO). This model is a guideline for developing games and has the following guidelines:

- Input: design of the instructional contends, following six different types of characteristics: fantasy, rule/objective, sensorial stimulus, challenge, mystery and control.

- Process: cycle (mechanics) of the game and feedback from the system.

- Outcome: performing the training goals and specific learning results.

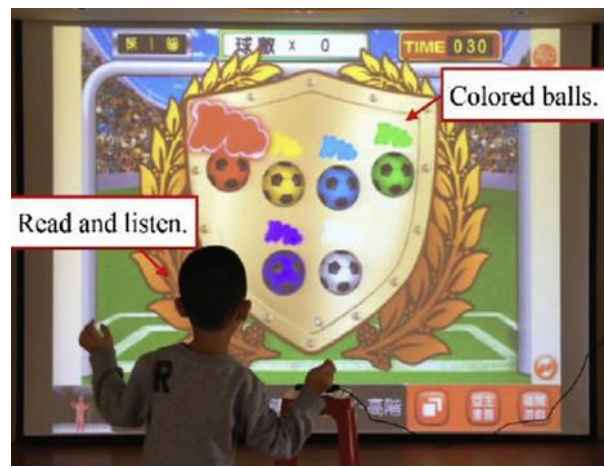

Fig.7. Boy playing “The Goalkeeper”. Source: Hsiao and Chen (2016).

The objective of the game was the learning of six colors and their respective names in English, the second language of children, while simultaneously performing movements.

An experiment was performed comparing the traditional method of color teaching (control group) with the gesture-based games method (experimental method). Results show that the different learning approaches 
affected the performance of content assimilation and the motor skills of participants.

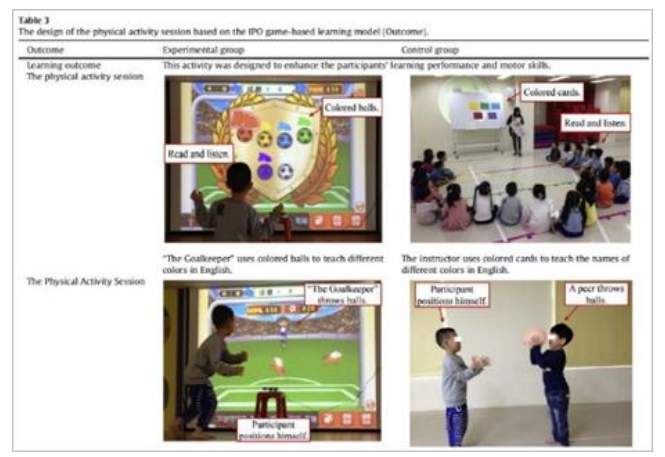

Fig.8. Design of experiment detailing the Outcome stage, of IPO model. Source: Hsiao and Chen (2016).

There was improvement in learning and motor skills performance for those who used the gesture-based games approach to complete the tasks. This approach reinforces the memory of participants and they were able to understand more easily the educational materials, improving their learning performance and reinforcing their motor skills. Even being used only in the teaching of a foreign language, the gesture-based games model was considered as promising to be used in other cases.

D. Meet Brownie: digital activities for children from bilingual schools

Digital activities from project Meet Brownie were developed to be used in classroom with mediation of the teacher. Using languages HTML5, CSS and JS, the activities contain exercises, animations and interactive games to be used in different browsers and are designed for all students in the classroom. The digital material has two volumes: Meet Brownie Blue and Meet Brownie Yellow.

Target group are three and four years old children studying in bilingual schools, where the English language is the mean for learning other disciplines and concepts.

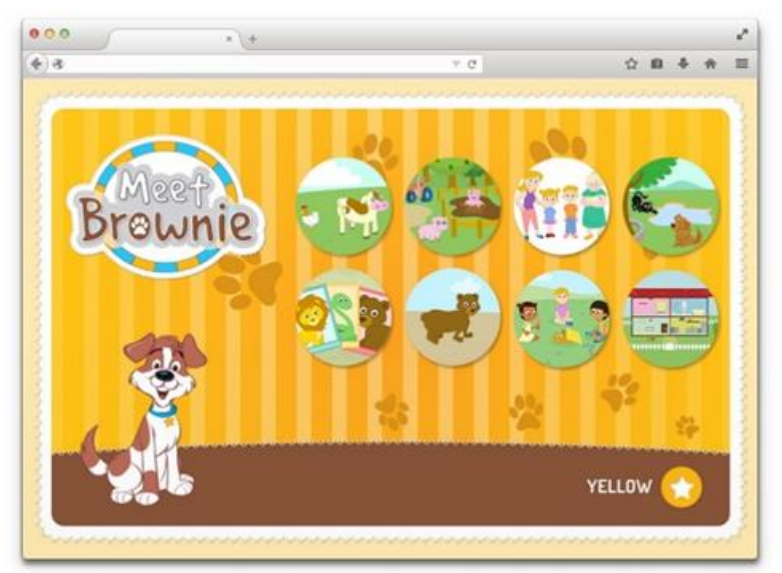

Fig.9. Layout of the main interface of "Meet Brownie Yellow". Source: Project "Meet Brownie".

Learning Factory S/A, publishing company of "Cultura Inglesa", masterminded the project and created a partnership with PICTUS, a company of graphic and digital design, for development of activities. Having a structured briefing and the first scripts of activities, created by both teachers and editors, the production of the activities was started following a methodology in two phases, summarized as follows and detailed in the paper from Brunnet (2015).

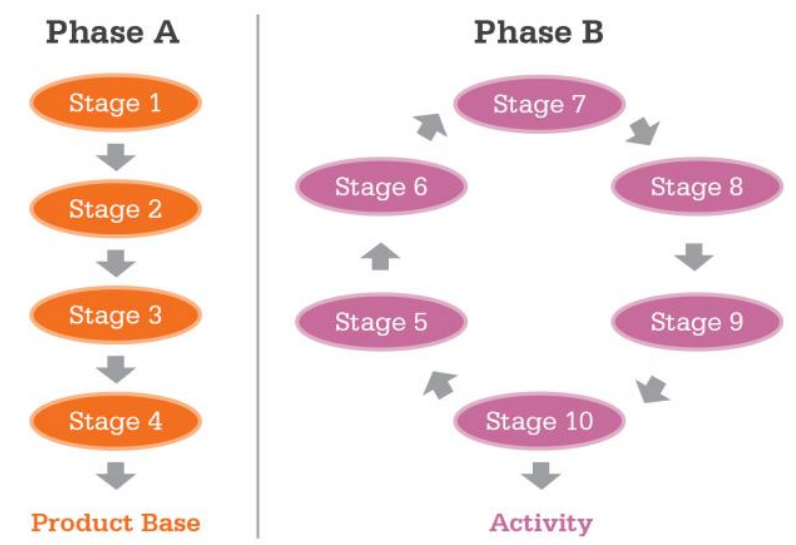

Fig.10. Phases A and B of project "Meet Brownie". Source: Brunnet (2015).

\section{Phase A-Development of the product base.}

- Stage 1: Knowledge about the market, target public, object and project concept. First analysis of activities content. Verification of technological feasibility and definition of technology to be used;

- Stage 2: Macro architecture of information, mechanics and gameplay. Definition of elements and resources to be used and navigational flow. Production of initial wireframes and storyboards. Validation and adjustments in wireframes and storyboards.

- Stage 3: Layout of main interfaces. Validation and adjustments in lay-out and navigational flow. Start of programming the base in HTML5+CSS+JS.

- $\quad$ Stage 4: Testing in the use place and finalization of programming the base.

\section{Phase B: Development of activities}

- Stage 5: Detailed analysis of the script of the activity to be executed, generation of ideas and creation of sketches of the other complementary illustrations and storyboards of the activity. Validation of concepts and sketches.

- Stage 6: Beginning of the art finishing of drawings. Validation and adjustments of trace, colors, shapes and sizes of elements created with tests in the place of use.

- Stage 7: Finishing of illustrations after testing and creation of animation frames using sprite technique.

- Stage 8: Programming of animations and programming of the first interactions of activities in HTML5+CSS+JS. Insertion of audios. Validation, tests and adjustments. 
- Stage 9: Finishing of programming and validation and feedback from activities with full operation. Adjustments in details of animations and interactions, when needed.

- Stage 10: Final tests in classrooms. Validation and final adjustments.

Analyzing the adopted methodology it is observed the use of the technique of prototyping and tests in several stages, which greatly contributed to integrate the multidisciplinary present in digital projects focused on education.

During activity "On a Farm II", the character walks in a farm, teaching vocabulary from this context such as fruits and vegetables, in English. Clicking over all the elements of the scene, the activity returns an audio feedback with a speech of the character containing the vocabulary intended to be learned by the children (e.g.: "Look! An egg!") and an animation of the scene. The design of characters and scenes, the audios with children's voices and the familiar elements with simple aesthetic and strong colors in the scenes makes easy for the children to identify themselves, creating engagement.

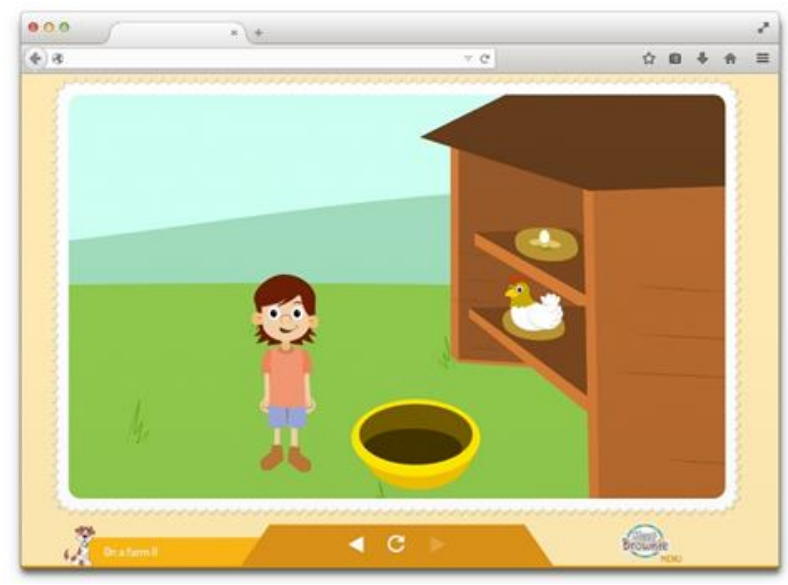

Fig.11. Print screen of animation of activity "On a Farm II". Source: Project "Meet Brownie".

In this project, the iterative prototyping and tests were essential to, for instance, setting colors and sizes of elements, the timing of some animations and games and the difficulty to understand some concepts. The visual and sound feedback included in the iteractions was very important, since each activity works with a different mechanics. Tests were executed with teachers from "Cultura Inglesa" who simulated the teaching-learning dynamics using the activities in the classroom space.

\section{E. Synthesis of the analyzed digital experiences}

The synthesis executed considers important aspects regarding the development process and the use of objects resulting from the four previously detailed experiences. Those aspects were evaluated as relevant also by the authors of the papers reporting the experiences.

Regarding the use of the games/activities analyzed, both the "In Digestion/Treasure Puzzle" as well as "The Goalkeeper" illustrate the importance of creating engagement of students during the activities in order to potentiate the teaching-learning process, the memorization and understanding of the educational content. In different ways, the analyzed papers also approach the importance of feedback, both to keep the engagement as well as to make teaching effective, by corroborating the understanding regarding what was presented.

Regarding product development, participative observation was a technique used on the four cases, sometimes for analysis of experiences, sometimes to receive inputs used to improve those products, from students or teachers.

Integration and participation of the target-public was essential during the development of "Beelight", a significant contribution for improving the product being reported.

During the studies of the experiences analyzed in this paper, improvements were reported and some problems identified for applying the materials. Limitations presented were normally regarding the small scale of the public in which the objects were applied, which disallows to be precise about their effectiveness.

\section{Closing Remarks}

In face of world technological changes, of new habits of children (and adults) and uncertainties in the field of teaching-learning, it is essential that educational materials, the system, utilization context and development processes are rethought both regarding their roles as well as regarding the concept, content and interactive possibilities.

According with Portugal (2014), how the information is made available, transmitted and organized in learning environments implies a series of factors that shall contribute towards the teaching and learning process or not, altering relationships and implies interactions between teachers and students. Assuming that the work with the student of contemporary cannot be limited to the reading and writing process, but rather to an entire hypermedia language.

During analysis of the studies presented in this paper, it was also possible to understand the impact of those transformations on the behavior of students and educators during teaching-learning dynamics. The engagement in one activity and the attitude of actively exploring the knowledge proved to be essential for the learning in current days.

Besides, from the analysis of the process and results, it was possible to find good methodological solutions for the project of those materials, such as the participative investigation, the iterative prototyping, pilot tests in places where they will be used, as well as to understand some of the benefits and difficulties of using them in school environment. Those methods and techniques will contribute to the project of teaching-learning experiences.

Finally, from the investigation performed, it is possible to understand that the methodologies adopted in game projects and digital activities must contemplate the effort 
of involving students and teachers in the process, seeking to improve the efficiency of the materials under an interactive production process. When new materials are created and tested and the way in which they may contribute in the process of knowledge building by the interaction subject-object is understood, it becomes possible to develop systems that use this potential and that better adapt to the needs of the students, teachers and educational institutions of today.

\section{REFERENCES}

[1] A. C. Ramal, Educação com Tecnologias Digitais: Uma Revolução Epistemológica em Mãos do Desenho Instrucional. In: Educação Online - Teorias, práticas, legislação e formação corporativa. Marco Silva (org.). São Paulo: Loyola, 2003.

[2] A. Duncan, "What Can Technology Do for Tomorrow's Children?", 2015, available in: https://medium.com/bright/ what-can-technology-do-for-tomorrow-s-children3357831 990c7, access in april 13th, 2016. S.p.

[3] A. L. Battaiola, "Jogos por computador -histórico, relevância tecnológica e mercadológica, tendências e técnicas de implementação," XIX Jornada de Atualização em Informática, Curitiba, SBC, v. 2, p. 83-122, 2000.

[4] C. Portugal, Design, educação e tecnologia, Rio Books, 2013.

[5] "Hypermedia E-book as a Pedagogical Tool in a Graduation Course", IJMECS, vol.6, no.9, pp.8-14, 2014. DOI: 10.5815/ijmecs.2014.09.02

[6] "Design em Situações de Ensino-aprendizagem. Um diálogo Interdisciplinar". Thesis (PHD in Design), Pontifícia Universidade Católica do Rio de Janeiro, Rio de Janeiro, 2009.

[7] C. Portugal and R. Couto, Design em situações de ensinoaprendizagem In: Estudos em Design (Online), v. 18, p. 01-22, 2010.

[8] H. Hsiao and J. Chen, "Using a gesture interactive gamebased learning approach to improve preschool children's learning performance and motor skills", Computers \& Education, v. 95, p. 151-162, 2016.

[9] J. Huizinga, Homo ludens: o jogo como elemento da cultura Editora da Universidade de S. Paulo, Editora Perspectiva, 1971.

[10] J. Mcgonigal, A realidade em jogo: por que os games nos tornam melhores e como eles podem mudar o mundo, Rio de Janeiro, BestSeller, 2012.

[11] J. Piaget, O nascimento da inteligência na criança. Trad. Álvaro Cabral, Rio de Janeiro, Zahar, 1975.

[12] K. Lowe et al. "Learning objects and engagement of students in Australian and New Zealand schools", British Journal of Educational Technology, v. 41, n. 2, p. 227-241, 2010.

[13] L. D. Costa, "O que os jogos de entretenimento têm que os jogos educativos não têm”. In: VIII Brazilian Symposium on Games and Digital Entertainment, 2009, p. 8-10.

[14] L. S. Vygotski, “A formação social da mente", M. Cole et al (Org.), São Paulo, Martins Fontes, 1991.

[15] L. Tractenberg and R. Tractenberg, "Design Instrucional na Educação Corporativa" In: RAMAL, Andrea (Org.). Educação corporativa: fundamentos e gestão, Rio de Janeiro: LTC, 2012.

[16] M. Csikszentmihalyi, Flow: the psychology of optimal experience, USA, Harper Perennial Modern Classics edition, 1990.
[17] M. M. Alves and A. L. Battaiola, "Recomendações para ampliar motivação em jogos e animações educacionais," $X$ SBGames, Salvador-BA, 2011.

[18] M. Prensky, Digital natives, digital immigrants, On the Horizon (MCB University Press, Vol. 9 No. 5, October 2001.

[19] M. Silva, "Interatividade: uma mudança fundamental do esquema clássico da comunicação", Boletim Técnico do SENAC, Rio de Janeiro, v. 23, n. 3, p. 19-27, 2000.

[20] N. Brunnet, "A importância do processo de design na criação e desenvolvimento de materiais didáticos digitais", In: C. G. Spinillo; L. M. Fadel; V. T. Souto; T. B. P. Silva \& R. J. Camara (Eds). Anais do $7^{\circ}$ Congresso Internacional de Design da Informação/Proceedings of the 7th Information Design International Conference | CIDI 2015 [Blucher Design Proceedings, num.2, vol.2], p. 243256, São Paulo, Blucher, 2015.

[21] P. Freire, Pedagogia da autonomia: saberes necessários à prática docente, São Paulo, Paz e Terra, 1996.

[22] R. C. Grando, O conhecimento matemático e o uso de jogos na sala de aula, Thesis (PHD in Education), Faculdade de Educação, Universidade Estadual de Campinas, São Paulo. 2000.

[23] T. Brown, Design Thinking: uma metodologia poderosa para decretar o fim das velhas ideias, Rio de Janeiro, Elsevier, 2010.

[24] V. Nacher, F. Garcia-Sanjuan and J. Jaen, "Game Technologies for Kindergarten Instruction: Experiences and Future Challenges" In: Proceedings of the 2nd Congreso de la Sociedad Española para las Ciencias del Videojuego, 2015. p. 58-67.

[25] Y. Shen et al, "Beelight: helping children discover colors" In: Proceedings of the 12th International Conference on Interaction Design and Children, ACM, 2013. p. 301-304.

[26] Y. Vianna et al, Gamification, Inc: como reinventar empresas a partir de jogos, Rio de Janeiro, MJV Press, 2013.

\section{Authors' Profiles}

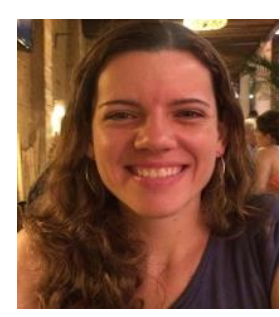

Natalia Brunnet was born in Porto Alegre, Brazil, on May $1^{\text {st }} 1983$. She is a Master student in Design at PUC-Rio (2016/2018). She is also an expert in Web Design, Strategic Design and Project Management.

Her research interests are new technologies for Education, digital products and projects with multidisciplinar teams. She has a particular interest in developing learning objects for children. Since 2008, she is a partner at PICTUS, a design studio in Rio de Janeiro, where she leads projects for Education and Training.

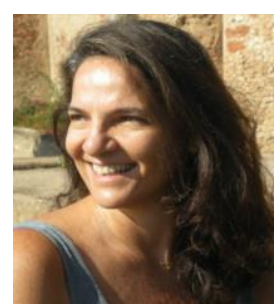

Cristina Portugal is a Doctor, Master and Bachelor in Design from the Pontifical Catholic University of Rio de Janeiro (PUC-Rio). She hold two POSDOC in Design. She is a Researcher at the Post Graduate Program in Design at PUC-Rio, President of Information Design Brazilian Society (SBDI) and an Editor of the journal Studies in Design. Her research covers Visual Communication 
within the research line Design, Technology, Education and Society.

How to cite this paper: Natália Brunnet, Cristina Portugal,"Digital Games and Interactive Activities: Design of Experiences to Enhance Children Teaching-Learning Process", International Journal of Modern Education and Computer Science(IJMECS), Vol.8, No.12, pp.1-9, 2016.DOI: 10.5815/ijmecs.2016.12.01 